\title{
A pastoral evaluation and responses to the challenge of spiritual insecurity in African pastoral ministry and Christianity
}

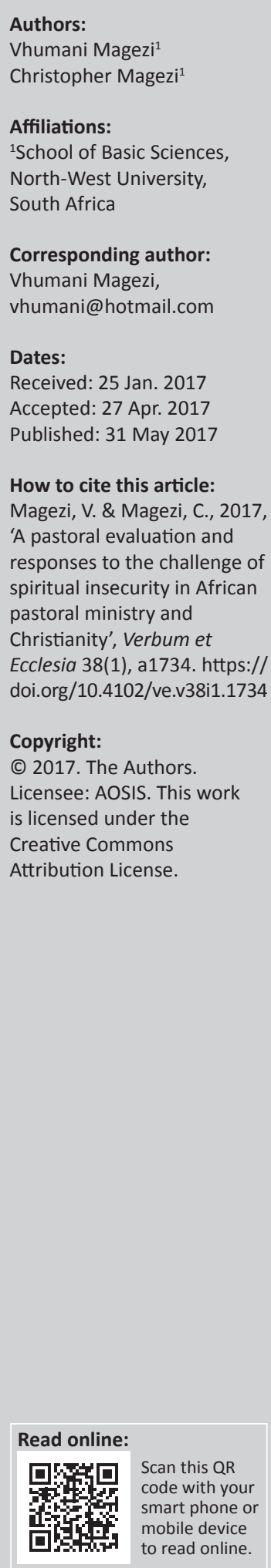

This article argues that there is a form of Christian syncretism operating in African Christians' use of traditional African powers to address their spiritual insecurity challenges that arises from their former traditional African worldview of spiritual powers. It provides an overview description of the nature of the spiritual insecurity which still grips African Christians by delving into the traditional African worldview of spiritual powers (such as the notions of a Supreme Being, lesser divinities, spirits and ancestors) and the centrality of traditional powers such as diviners in addressing this insecurity. After underscoring the aforementioned, this article proceeds to demonstrate three predominant views proposed by theological scholars as a response to the spiritual insecurity of African Christians. The first stance calls African Christians to discontinue with anything that is linked to traditional African spiritual worldview because Christianity entails a complete new ontological being. The second stance disapproves African Christians' reliance on traditional African powers and then proceeds to argue that Christian ministry should identify positives within the African spiritual world system and worldview that is useful and can be imported for use in contextualising the gospel. The third position advocates for Christians' continual reliance on traditional African spiritual powers in addressing their African contextual needs. In doing this, the weaknesses and strengths of these approaches are established with the view to outline an alternative biblical theological basis to ensure biblical Christianity in the challenging African contexts of spiritual insecurity. This article concludes by drawing from various theological responses to the spiritual insecurity of African Christians to ensure Christian ministry that is thoroughly biblical and contextual in African Christianity.

Intradisciplinary and/or interdisciplinary implications: This article discusses African spiritual worldview and its implications to practical Christianity. It is an interdisciplinary theological article that integrates African Christian theology and pastoral care. It contributes to the discussion on contextualising Christian practical ministry in Africa.

\section{Introduction and background}

There is spiritual insecurity among African Christians that arises from African Christians' disconnection with African traditional patterns (Banda 2005; Bediako 2004:23). African Christians have in their worldview and upbringing an approach to life, health and wellness that is linked to spiritual powers. Health, life and wellness result from harmony satisfaction and abiding by the spiritual code (Banda 2005:25; Light 2010:107; Magezi 2007:657; Mwaura 2006:137). The first code is that health and life is a result of happiness by spiritual powers, that is, Supreme Being, lesser divinities, ancestors and spirits. The second code is that evil powers, such as witchcraft and sorcerers, are kept at bay through ancestors' protection and protecting magic.

Good life, wellness and health are expected to be alright on an ongoing basis because of the balance of life forces whereby ancestors and associated spiritual beings are happy and also witches and sorcerers are kept at bay. Sickness or unhealthy is viewed as a breakdown of this equilibrium code or balance. In such a situation (times of sickness and problems), remedy is sought through diagnoses and through resultant intervention proposed by traditional African diviners (Imasogie 1983:60; Mbiti 1989:165-174; Nakah 2006:32; Sogolo 1991:182-185). Diviners have supernatural powers to communicate with the spiritual world where they are informed of the causes of the problem and the remedy to be applied. Diviners occupy the central role in addressing African people's problems in life (Imasogie 1983:60; Mbiti 1989:165-174). They play a connecting role between the human beings and the spiritual powers (Imasogie 1983:60; Mbiti 1989:165-174). They carry the inquiries of human beings to spiritual powers for causes and remedies. In turn, they 
bring responses from spiritual world to the living (Imasogie 1983:60; Mbiti 1989:165-174).

This means diviners play a central role in answering the why question regarding the happenings in life. Life issues always have clear causes and solutions. Upon conversion to Christianity, one breaks away from these so called evil powers. Conversion entails abandoning consultation of diviners, abandoning the spiritual powers that one has been depended on from their worldview upbringing. Considering that African people's life is intertwined with the spiritual world, conversion means one breaks away from his or her worldview and experiences. In doing so, one is abandoning what is familiar to embrace what is unfamiliar with the family, community and entire environment of the converted person being influenced by spiritual worldview. Christianity has a challenge to provide an alternative or system of care that replaces the abandoned one. The question is: Does Christianity provide a similar framework? Although being a Christian entails being under the care and protection of God, the challenge is that it does not provide a healing framework that at all times provide clear answers of why things happen.

The Christian notion that people do not always know with certainty why certain things happen leaves one in the dark regarding why they are experiencing problems. This approach makes one insecure. The question is how one can be treated if the causes and remedies are not clearly known. The insecurity arises from the fact that one cannot with confidence claim to be obtaining the right answers to their challenges. Christianity appears to be guess work that is divorced from concrete solutions to African people's challenges. The two systems worldviews of Christianity and traditional African powers create a tension within an African person. On one hand, one is a product of a familiar worldview with its clear positives and negatives, whereas, on the other hand, a totally new worldview is introduced to replace the old one. During this tension, African Christians then tend to revert to the previously abandoned traditional African religious forms of addressing the spiritual insecurity challenges, sometimes pejoratively called syncretism (Ejenobo 2009:77-78). That is, African believers reflect 'a religious syncretism that is suitable to their social requirements, going to church on Sundays, but consulting the traditional religious priests during the weekdays' (Ejenobo 2009:77-78). Magezi (2016:5) in his recent article Reflection on pastoral care in Africa: Towards discerning emerging pragmatic pastoral ministerial responses, observed that theological reflection has tended to focus on pastoral implications of ministry contextualisation as informed by what Masamba ma Mpolo's (2013:7-18) termed homo africanus defining elements as discussed in the next section. However, Magezi $(2010,2016)$ in agreement with Bowers (2009:94-100) about the huge focus on contextualisation at the expense of reflection on contemporary ministry challenges, commented that these intellectual preoccupations are at a tangent to what is practically happening in the lives of people on the ground. In response to this gap, African Reconstruction Theology has emerged with the aim of reflecting and providing pastoral care that seeks to restore and address the challenges experienced in many contemporary Africa communities (Gathogo 2007:101). Therefore, although there are many African people who are concerned about other challenges as argued by Reconstruction theologians, our focus in this article is on spiritual insecurity and the resultant resorting to African traditional powers as a means to address their spiritual insecurity by some African Christians.

The question is how one responds in a way that is sensitive to the African spiritual world context and the Christian biblical framework. In response to the situation, three predominant views are proposed by theological scholars. The first stance calls African Christians to discontinue with anything that is linked to traditional African spiritual worldview. Christianity entails a complete new ontological being. One has to totally disconnect with the traditional African spiritual powers. Spiritual world in the African sense is antithetical to Judeo-Christianity. The second stance is that Christian ministry should identify positives within the African spiritual world system and worldview that is useful and can be imported for use in contextualising the gospel. This focuses on natural strengths of African system to contextualise and make Christianity relevant. The third position advocates for Christians' continual reliance on traditional African spiritual powers in addressing their African contextual needs. This approach holds a position that African spiritual powers and God work in a synergistic way. They cooperate for the common good of people. One can adopt any of the two depending on context and solutions being sought.

In view of these responses, how can the issue of spiritual insecurity be addressed to ensure biblical Christianity. What principles could be drawn from various responses to ensure Christian ministry that is thoroughly biblical and contextual in African Christianity. In addressing this question, the first section will establish an overview description of the spiritual insecurity within traditional African worldview of spiritual powers and the centrality of traditional African diviners in addressing that insecurity. The second section will discuss three Christian responses to the spiritual insecurity of African Christians. The third section will provide a biblical-theological evaluation of spiritual powers and appropriate response. The final section will establish the pastoral guidelines for ensuring security in African Christianity.

\section{Establishing the common African worldview or views}

A considerable number of African theologians (Imasogie 1983:53-54; Ishola 2002:46; Light 2010:98; Lugira 2009:48-102; Mashau 2009:117; Mbiti 1989:76'; Turaki 2006:86; Wethmar 2006:249-250) concur about the common traditional African

1.Mbiti (1989:76) supports that in Africans' belief in spiritual powers, 'obviously there are local differences, but the pattern is fairly uniform throughout the traditional environment'. 
worldviews ${ }^{2}$ that run across all African cultures even though their expression varies. Ishola (2002) argues that:

the plurality of their expression [African beliefs] is due to over one thousand ethnic language groups, each with its own tradition, yet with uniformity in the various people's understanding of the nature of the world, the nature of human beings and their place in the world, and the nature of evil. (p. 46)

Mashau (2009) extends the list of the common African elemental beliefs by positing that:

the commonalities include, among others, belief in a transcendent God, a spiritual world, ancestral spirits, a hierarchy of powers, the notion of cosmic good and African communality, and the use of spiritual powers for good or bad. (p. 117)

However, within the unvarying beliefs of traditional African cultures is the foundational worldview of the interconnection between the spiritual and physical worlds (Dyrness 1990:44; Louw 2002:72; Lugira 2009:48; Mbiti 1989:74-85; Turaki 2006:34). Mbiti (1989) encapsulates the interconnection between the physical and the spiritual worlds in the statement that the:

spiritual universe is united with the physical, and that these two intermingle and dovetail into each other so much that it is not easy, or even necessary, at times to draw the distinction or separate them. (p. 74)

Various African cultures recognise that the spirit world is inhabited by many spiritual powers, which are in a hierarchical relationship with one another; acting capriciously as an unpredictable influence of good and evil in the lives of Africans (Imasogie 1983:53-54; Light 2010:99-109; Lugira 2009:36-63; Mashau 2009:117; Mbiti 1989:77-80; Turaki 2006:54-66).

In expanding the above-mentioned understanding, one should note that Africa is heterogeneous with diverse groups of people. Berinyuu (2005:153) noted this heterogeneity and clarified that there are two broad traditions in African theological reflection, which assist in discussing African theological issues. These are the liberation or Black theology dimension in South Africa and a focus on African indigenous cultures by other African countries. Another general distinction made is that when reference to Africa is done in theological discussion, the focus will be on Africa south of the Sahara. Despite this diversity, Masamba ma Mpolo (2013:7-18) provided a more useful operational definition of Africa. He usefully argued that there are clearly discernible elements that are common and can be found in different forms that homo africanus are organised. These are sanctity of life, relation between illness, misfortune and sin, spirits and ancestors in the life of the community, and life experience as a whole. This premise on the meaning of Africa is generally

2.Magezi (2006:6-9), Hesselgrave (1991:199-102) and Kraft (1999:384-386) define people's worldview as their integral way of perceiving reality in the world. Likewise, Naugle (2002:260, 151), who provides a comprehensive historical discussion of the concept of worldview, posits that a worldview 'refers to a person's interpretation of reality and a basic view of life. Hiebert (2008:28) further acknowledges the aforementioned concept of worldview by suggesting that 'world-views are models of reality - they describe and explain the nature of things - and models for action they provide us with the mental blueprints that guide our behaviour'. upheld in scholarly discussions on Africa (Berinyuu 1988; Bowers 2009; Louw 2008; Magezi 2006, 2007, 2010, 2016; Masamba ma Mpolo 2013; Mbiti 1989; Milingo 1984; Mwaura 1994, etc.). Given this, the subsequent subsections expound the nature of African spirituality (i.e. the belief in spiritual powers) as a significant African phenomenon that poses spiritual insecurity within Africans. This spiritual insecurity persists among some Africans who then convert into Christianity (Bediako 2004:23). African Christians' spiritual insecurity is evident in the form of Christian syncretism operating in African Christians' continual use of traditional African powers (cf. Anderson 2001:98-11; Banda 2005:2-6; Kok 2005:95-101; Kunhiyop 2012:59; Michael 2013:99; Wijsen 2000:37-60).

\section{Africans' spiritual insecurity from their beliefs in invisible powers}

\section{Africans' spiritual insecurity because of the Supreme Being (God)}

Importantly, many scholars (cf. Agyarko 2010:52-54; Imasogie 1983:66; Lugira 2009:36; Mbiti 1989:15-77) agree that in the African concept of the spiritual world, the Supreme Being is the head of these spiritual powers, because he is the sole creator of everything that exists, including the lesser spiritual entities. The fact that African people believe the Supreme Being to be the sole creator of all existing things implies that they perceive God as eternal (the one who does not have a beginning or an end) (Mbiti 1989:30-36). Lugira (2009:36) summarises the predominant African belief in the Supreme Being as the sole creator of everything, in this way: 'most Africans' oral traditions have pointed to the existence of a power above which there is no other power, a Supreme Being, Creator, and Originator of the World' Likewise, Mbiti (1970:45, cf. Turaki 1999:27) argues that 'our written sources indicate that practically all African peoples consider God as creator, making this the commonest attribute of the works or activities of God'.

Nevertheless, in traditional African belief, the Supreme Being is not directly involved in everyday human activities, because he is transcendent and remote from the physical world (Lugira 2009:36-46; Turaki 2006:59-61). However, the transcendence and remoteness of God in traditional African belief does not eliminate the concepts of God's omnipresence (his presence in all places, at all times), omniscience (his allknowing) and omnipotence (his all-powerfulness) (Mbiti 1970:3-18, 1989:29-36). That is why:

African theologians and scholars speak about the transcendence of God, the Supreme Being, and claim that the space between God and human beings is filled with a hierarchy of gods, divinities and spirits who are sometimes called the intermediaries of God. (Turaki 2006:61)

Firstly, this belief seems to come from traditional African stories, which state that the Supreme Being has prescribed various 'duties or responsibilities' to the lesser spiritual beings interacting with the physical world (Turaki 2006:56). Secondly, it also appears to spring from the traditional 
African belief that God cannot be approached directly (Dyrness 1990:48; Lugira 2009:46-48; Mbiti, 1989:82; Nurnberger 2007:75; Turaki 2006:56-61).

In this way, the Supreme Being is 'the ultimate peak of the pyramid, but he is too remote and inaccessible to play a role in practical life' (Nurnberger 2007:75). That is, many Africans believe that:

most of the things humans need fall within the sphere of the authority of lesser spiritual beings, there is no need to go to God or bother him unless the lesser beings prove inadequate when it comes to providing powers, needs, purposes and security. (Turaki 2006:57)

In this same respect, because God does not have direct interaction with the physical world, it is not usual for him (God) to be viewed as the fundamental agent of African people's misfortunes (Westerlund 2006:79). However, the preceding thought seems to downplay the African belief that the lesser spiritual powers are the agents of God. That is, if the lesser spiritual powers are working in conjunction with God, as his agents, it follows that the causes should be attributed to the Supreme Being. Regardless of this, in traditional African worldview, God's existence is acknowledged, yet he commands less fear than the lesser spiritual powers (Turaki 2006:56).

\section{Africans' spiritual insecurity because of the lesser spiritual divinities or gods}

Having probed the nature of the African Supreme Being; Lugira (2009:46-47) argues that the lesser spiritual beings 'are ranked according to their nearness to God'. The closest spiritual beings to God are the lesser spiritual divinities or gods (Lugira 2009:46-47). Turaki (2006:56-61), Mbiti (1989:74-77), Light (2010:102-103) and Lugira (2009:46-47) understand these lesser spiritual divinities to be God's associates or intermediaries, who are in conjoint operation with the Supreme Being in the spiritual and physical worlds. Mbiti (1989) puts it this way:

divinities are thought to have been created by God, in the ontological category of the spirits. They are associated with him (God), and often stand for his activities or manifestations either as personifications or as the spiritual beings in charge of these major objects or phenomena of nature. (p. 75)

In this way, Africans believe that these lesser spiritual divinities reside in physical objects such as bushes, dams, forests, woods, mountains and rivers (Idowu 1973:174; Lugira 2009:41; Mbiti 1989:79; Turaki 2006:56).

The places which the lesser spiritual divinities dwell are considered sacred; thus, they are regulated by various taboos ${ }^{3}$ by which human beings are to maintain harmony with the

3. Here, a taboo is defined by the Oxford Advanced Learners Dictionary (2010:1518) as 'a cultural or religious custom that does not allow people to do, use or talk about a particular thing as people find it offensive or embarrassing'. In agreement with the above definition of a taboo, the Evangelical Dictionary of World Missions provides us with a relevant traditional African religious significance of the word (Akins $2000: 928)$. That is, religiously, a taboo is used to accommodate African peoples' fea of the invisible powers, such as ancestors, lesser divinities and et cetera. In this way, a taboo is neither interested 'with what is morally right or wrong'; instead, it is concerned with safeguarding Africans from the offenses which emanate from the invisible forces. Therefore, peace and prosperity in some African communities are guaranteed by the maintenance of a 'health balance between good and bad taboos'. lesser spiritual divinities (Magezi 2007:657; Mwaura 2006:137). Magezi (2006:9); Louw (2002:72) and Mbiti (1989:79) argue that, any fracture of these environmental taboos is a serious offence to the spiritual powers. It is claimed that the spiritual divinities will cause multifaceted diseases, sicknesses and misfortunes in the lives of human beings (Louw 2002:72; Magezi 2006:9; Mbiti 1989:79). In Louw's (2002:72) view, this is one of the reasons for African people perceiving life as 'an integral whole of cosmic and social events. This implies that when one breaks society's moral codes, the cosmic ties between oneself and the community are broken'. Given this, there is a serious need in traditional African belief for human beings to live in harmony with their sacred environments.

However, although human beings can consciously live in accord with the sacred environmental seats (such as mountains, bushes, etc.) of the lesser spiritual divinities, it is difficult to understand the assigned roles of these divinities (i.e. assigned by the Supreme Being). This is because these lesser spiritual divinities 'are seen as mediators acting with the sanction and knowledge of God himself although at other times they act as independent agents' (Turaki 2006:59). Mbiti (1989:79) understands this to denote that not all lesser spiritual beings operate within the contours of God's good purposes in his creation, because they are 'ontologically nearer to God: not ethically, but in terms of communication with him'. Thus, although the lesser spiritual divinities are responsible for providing humanity with 'aid and guidance in the mundane matters of everyday life', they still cause serious uncertainties and doubts among African people (Turaki 2006:61).

Nevertheless, despite the spiritual insecurity of African people which emanate from these lesser spiritual divinities, some Africans still make 'requests concerning their needs and desires' (Lugira 2009:46). These requests are made through 'offerings and sacrifices' to the lesser spiritual divinities 'for health and happiness, successful crops, the birth of healthy children, and protection from evil' (Lugira 2009:46). The above-mentioned description of the nature of the spiritual divinities enables one to conclude that Africans live under constant fear of these spiritual divinities, because they can either bless or harm humans, depending on the state of the volatile relationship between humanity and these spiritual divinities (Imasogie 1983:66).

\section{Africans' spiritual insecurity because of the spirits}

According to Mbiti (1989:78) and Igba (2013:28), there is no misconception in traditional African belief concerning the position of the 'spirits and the living dead' in their relationship to God. African people believe that 'spirits are the destiny of man and beyond them is God. Societies that recognise divinities regard them as a further group in the ontological hierarchy between spirits and God' (Mbiti 1989:78).

Lugira (2009:50) understands that some deceased individuals' spirits are regarded as 'ancestors and others are the spirits of 
the ordinary dead-that is the dead of the community who are neither ancestors nor identified as outstanding members of the community'. That is, the spirits are the deceased people, who are not remembered within their clans, tribes or families (Mbiti 1989:83-84; Reed \& Mtukwa 2010:148-149; Salala 1998:133). These spirits are ever-present, although Africans are not cognisant of the specific location where they are or what they are doing (Mbiti 1989:83-84; Salala 1998:133). Nevertheless, all these spirits are potentially malicious because they can possess people and inflict all kinds of suffering (Mbiti 1989:80-81; Nurnberger 2007:10). In this regard, human beings need to be protected from them (Mbiti 1989:80-81). Therefore, people are safeguarded from these malicious spirits and ghosts through the use of traditional medicines such as 'amulets on their necks and ropes tied to their hands', which are offered by traditional African diviners (Imasogie 1983:63; Mashau 2009:119-120). However, regardless of the protection which people can obtain from traditional African practitioners, Africans are continuously afraid of this category of spiritual powers (Mbiti 1989:80-81).

\section{Africans' spiritual insecurity because of the ancestors or the living dead}

The ancestors are those blood-related members of the family, clan or tribe, who have lived an outstanding life during their lifetimes and who have presupposedly acquired supernatural powers after death, which enables them to function as both guardians and protectors of their living descendants (cf. Bediako 2004:23; Lugira 2009:48-50; Nyamiti 2006:3; Oladosu 2012:160-161). In the traditional African worldview, the ancestors are the most respected and feared spiritual powers (Dyrness 1990:48; Oladosu 2012:161). Therefore, ancestors are believed by Africans to be a dominant category among the spiritual powers (Dyrness 1990:48; Reed \& Mtukwa 2010:148; Triebel 2002:193). In Dyrness (1990:48) and Mbiti's (1989:82) view, the ancestors are believed to be the dominant spiritual category because they are the closest spiritual powers to living people. Mbiti puts it this way:

... the living-dead are therefore the closest link between men and God: they know the needs of men, they have recently been here with men, and at the same time they have full access to the channel of communicating with God directly or according to some societies, indirectly through their own fore-bearers. (p. 82)

This implies that, in traditional African belief, the ancestors are present with the living, and living people rely on them for their prosperity in life (Triebel 2002:187). Oladosu (2012) puts it this way:

\footnotetext{
... the position and function attached to the concept of ancestral veneration among the Africans identifies their community setting as a continuing unit. This continuity shows influence between the members still here on earth and those that are in the world beyond as the ancestors. (p. 161)
}

However, the problem which has arisen in ancestral belief is that, although the ancestors are respected, they are nevertheless feared by the living (Ashforth 2005:208-209; Dyrness 1990:48, 50; Oladosu 2012:161-162; Triebel 2002:190). That is, although in the preceding paragraph, the ancestors are regarded as protectors and guardians of the living, they can still bring curses upon living people in the form of 'suffering, instability, poverty, misfortune, sickness and even death' (Dyrness 1990:48; Mbiti 1989:83; Triebel 2002:192). In this instance, the ancestors are constantly watching over the living but any human deviance from 'the inherited traditions' incurs curses, whereas the opposite (i.e. compliance with traditions) brings blessings to the living (Nurnberger 2007:66). Such inherited traditions include Africans' taking care 'to follow the proper practices and customs, especially regarding the burial or other means of disposal of dead bodies', as well as making 'libation and food offerings' to ancestors (Mbiti 1989:83).

Interestingly, Ashforth attempts to substantiate the ancestors' unpredictability by locating the origin of their capacity for causing good and evil in their flawed character (Ashforth 2005:209). He argues that they 'are still human in origin and take with them their human characteristics into the otherworld' (Ashforth 2005:209). Therefore:

if the ancestors carry into the afterlife the same limitations and negative human qualities they had as living members of families - absent, abusive, jealous, unreliable, tyrannical or even just plain evil - then their descendants are sorely in need of other spiritual powers to guard their security and prosperity. (p. 209)

If this is true, one could contend that the ancestors foster real spiritual insecurity within Africans. However, regardless of some African peoples' spiritual insecurity arising from the unpredictable behaviour of the ancestors, Triebel (2002) asserts the centrality of ancestors in African traditional beliefs, as he concludes that:

Because the ancestors cause misfortune on the one hand and because on the other hand only they can grant fortune, wellbeing, life, and a good living - that is, fullness of life- - they alone are venerated... Therefore this cult is really the central aspect, the centre of African religion. (p. 193)

\section{Africans' spiritual insecurity because of the African concept of spiritual causality behind all existential challenges}

The fact that many African people believe in the supernatural causes of diseases and sicknesses does not imply that Africans do not believe in any form of natural causes for their existential challenges (Hastings 1976:64). Hastings (1976:69), Magezi (2006:7-8), Mwaura (1994:62-102), Westerlund (2006:75-76) and Sogolo (1991:182) provide a helpful distinction between the Western and African way of perceiving the causes of diseases and sicknesses. Magezi (2006:7), Westerlund (2006:75-79) and Mwaura (1994:62-102) indicate that, whilst African people possess a 'personalistic view' (supernatural causes from the spiritual entities) of illness; the Western world believes in the 'impersonalistic

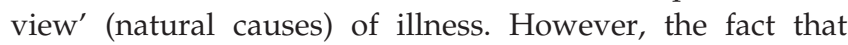
Africans believe in the personalistic view of illness does not 'diminish the naturalistic causes of illness such as germs, viruses or bacteria' (Magezi 2006:7). 
In this way, when African theologians and scholars speak of African beliefs in spiritual causes of illness, it does not mean that they are not cognisant of the fact that some forms of sickness have 'natural or organic causes' (Magezi 2006:7). Instead, these African theologians and scholars are arguing for the centrality of 'the supernatural or spiritual causation of illness' within the traditional African worldview (Magezi 2006:7). Sogolo (1991:182-185) inclines to Magezi and Mwaura's understanding in his categorisation of the supernatural causation of illnesses as 'primary', whilst the natural causation is 'secondary'. Given this, Sogolo (1991) carefully concludes that in traditional African thinking:

a clear dichotomy between the natural and supernatural (causation) does not exist...even if it does; the apparent conflict in people's explanations of illness may still be resolved by invoking the difference in principle between primary causes and secondary causes. (p. 184)

Furthermore, Magezi (2006:6), Lugira (2009:96-98), Idowu (1973:190-202), Ashforth (2005:106-108) and Mbiti (1989:165) agree that (besides the supernatural and natural causation of sickness, diseases and misfortune) Africans also believe that diseases, sicknesses and misfortunes are caused by humans (human causation), such as witches ${ }^{4}$ and sorcerers. Nevertheless, even though witchcraft is practised by human beings to injure other people; scholars agree that witchcraft always has a spiritual dimension (Ashforth 2001:207; Haar 2007:3; Lugira 2009:98). In this way, there is a connection between the human and spiritual dimension of witchcraft, as Ashforth (2001) helpfully substantiates that witchcraft includes:

... practices where human action directed towards evil ends engages with invisible forces that are variously conceived of as physical, human or extra human in nature. ... The misfortunes which witchcraft can cause are unbounded: illness, death, unemployment, car accidents, divorce, family discord are all within their capacities. (p. 207)

On the contrary, sorcerers or magicians are people who have the ability to control the supernatural forces through inventing various human mechanical means (Idowu 1973:190). In doing this, these people can live outside the influence of the spiritual powers, because they can have control over their own fate and life interests (Idowu 1973:190). In this setting, Lugira (2009:98) posits the significance of sorcerers in his assertion that, a sorcerer 'makes the unknown less threatening and provides psychological reassurances for potentially difficult or even dangerous situations. Ritual acts and talismans provide magical protection from unknown dangers around the world'. However, Lugira (2009:98) and Mbiti (1989:165) concur that a sorcerer or a witch can intensify the spiritual insecurity of African people. This is because the sorcerers or witches can manipulate their powers to impinge diseases, sicknesses and misfortunes towards other people (Lugira 2009:98; Magezi 2006:9; Mbiti 1989:165). Given this, one can sustain that:

4.Lugira (2009:99-100) explains that witches are those African people who are 'possessed by extra-human forces that can do evil or harm' to others. They (witches) can either inherit extra-human powers from their parents (which implies that on can be born a witch), or els cause multifaceted existential challenges to other people, such as 'failure to bear children, diseases, failure in life, illness, and death' (Lugira 2009:99). In this way, witches are capable of causing social and economic unrest among African people (Lugira 2009:100)
Africans recognise other types of forces that are neither superhuman nor simply human but lie somewhere between. These mystical forces include magic, witchcraft, and sorcery. Like spiritual forces, they affect people's lives and the lives of their community. (Lugira 2009:96)

\section{The centrality of African traditional powers in solving Africans' spiritual insecurity}

Mbiti (1989:165-174) helpfully classified the traditional African practitioners into two categories: The 'medicine men, and the diviners and mediums'. Nakah (2006:32) agrees with Mbiti in his categorisation of traditional African practitioners as the herbalist (medicine men) and the diviners (including spiritual mediums). However, the distinction between the diviners and medicine men is unclear, because one can hardly see a traditional herbalist who can provide any form of traditional medicine without practising some form of divination $^{5}$ (Nakah 2006:32; Sogolo 1991:185). This depicts the centrality of divination within the traditional African practitioners (of both categories) because their 'primary concern is with the patient's background in socio-cultural and in divine/supernatural relations' (Sogolo 1991:182). In agreement, Imasogie (1983:60) maintains that, because in the traditional African worldview, every existential challenge has a supernatural cause; the traditional African practitioners are responsible in assisting people to 'look beyond physical events to their spiritual etiology'. That is, even though the traditional African medical practitioner is concerned with the natural dimension of diseases, sicknesses and misfortunes, the supernatural dimension is fundamental in the diagnoses, because all African existential challenges emanate from a metaphysical aspect of their interpretation of reality (Mbiti 1989:162-174; Sogolo 1991:177-182).

Furthermore, Mbiti (1989) endorses that, in the midst of various existential challenges (which emanate from the supernatural entities such as spirits, ancestors, witches and sorcerers), the African traditional practitioners detect the:

cause of the sickness, find who the criminal is, diagnose the nature of the disease, apply the right treatment and supply the means of preventing the misfortune from occurring again. (p. 165)

This implies that the medicine men and diviners are to be understood as:

able to decipher the past, the present and the future - as well as to uncover the human and the spiritual causes of events and the possible solution to the problems of life. (Imasogie 1983:60)

If this is the case, just like the Western specialists ${ }^{6}$; the medicine men and the diviners do not seek to change the 'normal course of events', because 'the order of nature is

5. However, this does not necessarily mean that there are no traditional herbalists who do not practice the aspect of divination.

6.Sogolos (1991) argues that the Western specialists and traditional African practitioners seem to concur that 'events of misfortune will always occur' to their patients under seem to con the cur the treatment. That is, both the Western specialists and traditional African practitioners cannot cease the events of misfortune to happen in the lives of people. Instead, they are capable of guaranteeing of misfortune. Therefore, "when the practice of divination in traditional Africa is seen in this way, it is clear, contra Horton, that traditional explanatory models are not intended for control of natural phenomena' (p. 179). 
believed to be laid down and it is not subject to change by mortals' (Sogolo 1991:179). In this circumstance, one can conclude that the traditional African diviners are central in solving the spiritual insecurity of African people.

In view of the above discussion, the question that arises is: How are Christians responding to the challenges of spiritual insecurities in Africa?

\section{Christian responses to the spiritual insecurity of African Christians An approach that challenges Christians to discontinue using African traditional powers}

The first position comprises a considerable number of scholars (Anderson 2001:98-11; Banda 2005:2-6; Kok 2005:95101; Kunhiyop 2012:59; Light 2010:21-22; Michael 2013:99; Nurnberger 2007:8-42; Wijsen 2000:37-60), who hold the view that African Christians ought to discontinue using African traditional powers to address their spiritual insecurity. These scholars find a form of Christian syncretism operating in African Christians' use of traditional African powers to address their spiritual insecurity challenges. However, they disapprove of Christians' use of traditional religious powers, because it is seen as incompatible with biblical salvation.

Many scholars (Kok 2005:95-100; Maimela 1991:9-10; Nurnberger 2007:8-42; Salala 1998:133-138; Wijsen 2000:4060) argue for the discontinuity of African Christians' use of African traditional powers, yet do not provide a solution to the problem of spiritual insecurity. Instead, they contend that the gospel in Africa has not penetrated all dimensions of African believers' lives, ${ }^{7}$ because many African Christians engage in both traditional African religion and Christianity in order to 'meet the dual social demand' of their spiritual challenges, which both religions offer (Kok 2005:95-100). In other words, traditional African religion obtains salvation for social ills, and protection from evil spirits and witchcraft, whilst Christianity offers the forgiveness of $\sin$ and the promise of eternal life (Banda 2005:2-3; Kok 2005:95-100; Maimela 1991:9-10; Salala 1998:133-138). In their view, this reflects that some African Christians do not perceive Christianity and African traditional religion as antithetical, which is contrary to biblical salvation which affirms that Christianity entails a complete new ontological being, that is, shifting from the kingdom of darkness to the kingdom of light.

However, despite the fact that many African Christians utilise African traditional powers, it should not be supposed that they place these agencies at the same level as Christ; because 'their involvement in Christianity is principled, structural and most important' (Kok 2005:99). Thus, African Christians' use of traditional religious powers is 'incidental and not out of intrinsic motivation' (Kok 2005:99). This view,

7.Nurnberger (2007:viii-15) identifies that the gospel has not yet penetrated some African believers' sense of spiritual insecurity, emanating from their fear of traditional religious spiritual threats such as ancestors, witchcraft and spiritual gods. however, still views Christianity as a religion that is incapable of meeting the criteria of a religion which African people long for - a religion that meets their existential necessities and wishes ${ }^{8}$ (Buthelezi 2011:6-15; Turaki 2006:15-19). Consequently the saving power of Christ is undermined, because he is seen as unable to address such spiritual insecurity.

Furthermore, a number of scholars (Brand 2002:69-70, 197198; Light 2010:107; Magezi 2006:6; Turaki 2006:15-35; Westerlund 2011:152-170) within this category have identified that in order to adequately address the spiritual insecurity of African believers, the worldviews of Africans need to be carefully considered. The foundational African worldview is that there is no event without a spiritual cause (Turaki 2006:15-35; Westerlund 2011:152-170). Many scholars in a volume of essays edited by Haar (2007) cogently propound, in Haar's words:

... an unusual angle of approach to the question of witchcraft in Africa, acknowledging the spiritual nature of the issue without losing sight of its material aspects'. These scholars contend that both the material and spiritual dimensions of witchcraft are significant, 'but it appears that no lasting solution to the problems posed by witchcraft beliefs and accusations will be found unless full account is taken of the spiritual dimension of the matter. (p. 3)

However, despite many scholars' serious consideration of the African worldview in addressing the spiritual insecurity of African Christians:

the spiritual beings are constantly the fears of most African people (Christians), and Christian theology must relate the victory of Jesus Christ in order to address these fears of the African people. (Michael 2013:99)

The truth is that 'God also provides answers to the fears and insecurities inherent in African world-view' (Anderson 2001:101).

The problem of the approach that disapproves African Christians' continual reliance on traditional religious powers is its danger in depicting Christ as foreign to Africans because it tends to demonise everything that is linked to the traditional African worldview or belief system. For example, in his ground breaking work, named, 'Theological Pitfalls in Africa', Biang Kato (1975) calls African Christians to discontinue with anything that is linked to traditional African spiritual worldview or religion. This is because Christianity entails a completely new ontological being, thus, one has to totally disconnect with the traditional African spiritual powers. Spiritual world in the African sense is antithetical to Judeo-Christianity. Although the above discussed theological stance correspond with scripture by rebutting African Christians' continual reliance on traditional African powers to address their spiritual insecurity, it is also true that its weakness lies in its destruction of the traditional heritage of

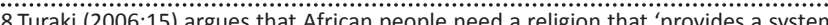
of belief and practice to deal with the struggles and problems of humantem of belief and practice to deal with the struggles and problems of human ife'. Buthelezi (2011.6) further posits that African Christians need a Christian faith, which delivers 'them from the practices that enslave them through fear of demonic powers'. 
African Christians (Bediako 1999:235). That is, it does not acknowledge the existence of the code of contacts between Christianity and traditional African worldview or religion that one can utilise to effectively communicate the relevance and sufficiency of the redemptive gospel of Jesus Christ to Africans' contextual needs, such as spiritual insecurity (Bediako 2004:23).

\section{An approach that focuses on natural strengths of the African system to contextualise and make Christianity relevant}

The second stance is that Christian ministry should identify positives within the African spiritual world system and worldview that is useful and can be imported for use in contextualising the gospel. Scholars that fit in this category are Bujo (1992), Bediako (2004), Nyamiti (2006), Pobee (1979), Milingo (1984), Kwesi (1984), Kabasele (1991) and many others. This approach is closely linked with the first stance yet it differs at the same time. However, even though this approach concurs with the first approaches' disapproval of African Christians' continual reliance in traditional African powers (as a means of addressing their spiritual insecurity challenges) because it is antithetical with the gospel, it further focuses on natural strengths of African system or worldview to contextualise the gospel and make Christianity relevant to African Christians. This position is more sympathetic to the traditional African worldview. We regard Bediako as a representative voice of African theologians because he offers doctrinal concepts which seek to make the gospel relevant and sufficient to address the spiritual insecurity of African Christians. Aho Ekue (2005) argues that:

There are those African theologians who are influenced by debate and culture, who stress the necessity of the translation of the gospel into the realities of the people. Here Bediako seems to be one of them. (p. 105)

For example, Bediako was interested in the question of theology and identity in African Christianity, as evidenced in his quest to develop African Christianity by initially deconstructing ${ }^{9}$ Christianity in Africa as a Western religion. Bediako's endeavour to deconstruct some African Christians' conceptualisation of Christianity as a Western religion emanates from his 'reading about the encounter of Western Christianity with African cultures' (Wagenaar 1999:365). Here, 'many questions rise to the surface', particularly about the negative attitudes of the Western missionaries 'to the indigenous cultures and traditional religions' of African people. In agreement with Stinton (2004:25-36), Bediako (1999:226-228) argues that most early Western missionaries' negative attitudes towards indigenous beliefs and cultural practices were so widespread that they were determined to destroy traditional African worldviews and cultural practices by conflating the Gospel and Western culture, and then imposing them upon African people.

Bediako (1999:230, 1992:227-228) argues that many early Western missionaries considered traditional African culture clarifying to African Christians that Christianity is a non-Western religion. and the African worldview both inferior and invalid compared to a Western 'civilised' worldview. African Christians were expected to accept both Christianity and the so called civilised Western thought in order for them to be authentic Christians (Bediako 1999:230-240), that is, Africans were expected to become like the Christian religious authorities (missionaries) in their cultural beliefs and practices (Bediako 1999:234-240). Bediako was dissatisfied primarily 'with the perspective from which the Christian enterprise' was undertaken by the early Western missionaries seeking to destroy the traditional heritage of African Christians by replacing it with their Western heritage (Bediako 1999:235). In this way, most early missionaries created an undesirable situation in which 'many African Christians will continue to be men and women living on two levels, half African and half European, but never belonging properly to either' (Bediako 2004:23). Because of this, Bediako saw the need for God to meet, and speak and reveal himself to African Christians 'in their particular circumstances' in a manner that reveals they are assured that they are 'authentic Africans and true Christians'.

Bediako's (1999:245) main theological interest was to decolonise or deconstruct Christianity as a Western religion on the basis of Christ's universality. Because of the universality of Christ, 'Christianity is fundamentally universal and so beyond any language, tribe or nation' (Wagenaar 1999:365-366). Furthermore, Bediako utilises his central theological approach to African theology that is known as the 'hermeneutic of identity' or 'mother tongue' hermeneutic to clarify Christianity as a non-Western religion (Olsen 1997:258). However, he is conscious of the dangers associated with his hermeneutic of identity approach. In his view, African theology does not seek to indigenise Christianity or theology as such; instead it attempts to confront culturally relevant issues, such as the problem of the foreignness of Christ in African Christianity, ${ }^{10}$ with the gospel (Olsen 1997:258). Here, Bediako advocates that African Christians can have an adequate understanding of the gospel through its application within traditional African categories or thoughts, such as the ancestral category (Aho Ekue 2005:105; Asamoah-Gyadu 2009:16; Kalu 2007:6-7). For example, in making Christ relevant in addressing the spiritual insecurity of African Christians, Bediako (1999:244-245) designated the ancestral category to Christ by paralleling God's revelation of himself in Jewish culture to African traditional culture, as well as by the divine-human nature of Christ. ${ }^{11}$ This approach seeks to dispel the foreignness of Christ in African Christianity that makes some African Christians viewing Christ as irrelevant in meeting their African contextual challenges,

10.Scholars such as Bediako (2004), Taylor (1963) Banda (2005), Chitando (2005) Hood (1990), Potgieter and Magezi (2016) and many more others understand that some African Christians continue to rely on traditional African powers to address their spiritual insecurity because they perceive Christ as foreign to their culture and see the Gospel as primarily a Western phenomenon. Such perceptions raise questions about their understanding of Christ's incarnation.

11.In order to fully understand how Bediako arrive to the treatment of Christ under the category of ancestor as a means of making Christ relevant in addressing the spiritual insecurity of African Christians, one should see Potgieter and Magezi's (2016) current article, namely 'A critical assessment of Bediako's incarnational (2016) current article, namely 'A critical assessment of Bediako's incarnational
Christological model as a response to the foreignness of Christ in African Christianity'. 
thus, continuously rely on their former traditional African powers. For instance, Bediako justifies the use of a category in which God was at work revealing himself in the same way he used the priestly category of the Jews. This approach is evident in Bediako's (1995) argument that:

\begin{abstract}
... a theology of ancestors is about the interpretation of the past in a way which shows that the present experience and knowledge of the grace of God in the Gospel of Jesus Christ have been truly anticipated and prefigured in the quests and the responses to the transcendent in former times, as these have been reflected in the lives of African people. (pp. 224-225)
\end{abstract}

Although this approach represented by Bediako takes seriously the traditional African worldview of spiritual insecurity, it seems to undermine the theological principles that are fundamental to Christian faith. For example, the application of the ancestral category on Christ seems to undermine the supremacy of Christ over the spiritual universe (Afeke \& Verster 2004:59). It is reminiscent of the danger of encouraging African Christians to continue thinking of Christ in view of their former traditional understanding of ancestors, in spite of the fact that Christ is the incarnated God, whose 'Lordship, authority and Supremacy can meet all spiritual needs' (Afeke \& Verster 2004:59). Perhaps, this is why the Christological paradigm and metaphorical expression of Christ as an ancestor lacks practical value at the grassroots level in African Christianity (Olsen 1997:251). Palmer (2008:65) similarly contends that many Protestant and Catholic theologians 'have referred to Jesus as an ancestor. Yet at the grass roots, there is still significant resistance to such a concept (ancestral concept)'. It is apparent that the conceptualisation of Christ as an ancestor might encourage African Christians to continue to perceive their natural ancestors as mediators between Africans and God (Reed \& Mtukwa 2010:157). African Christians might continue to look to both Christ and their natural ancestors for spiritual security, because they perceive no distinction between the two. Therefore, African Christians might continue to worship their former traditional ancestors by placing them 'in a position that only God should hold by offering to them sacrifices and oblations' (Reed \& Mtukwa 2010:157). Given this, even though this position makes Christ or the gospel relevant to African contextual needs, it is apparent that it has its own weaknesses as underscored in this section.

\section{An approach that advocates for Christians' continual use of traditional African powers}

The third position advocates for Christians' reliance on traditional African spiritual powers in addressing their spiritual insecurity. This approach holds a position that African spiritual powers and God work in a synergistic way. They corporate for the common good of people. One can adopt any one of the two depending on the context and solutions being sought.

This stance is championed by Brand (2002:198) who emphasise the authority of scripture pertaining to Christian faith and practice, yet he calls for an integrated approach between traditional African religion and the Christian means of salvation. Wethmar (2006:263) contests Brand's position, because he views Brand's allowance of African Christian use of traditional African powers as incompatible 'with the main tenets of Christian doctrine', whilst in principle advocating for Brand's position. However, in accordance with Mbiti's endorsement of African Christians' use of traditional religious powers, owing to Western utilisation of various specialists (such as psychiatrists) to deal with health issues, Brand (2002) provides the governing principle that:

These agencies (African traditional powers) should only be used if it does not distract one's faith in God.... Africans can continue to use the best means at their disposal to combat evil and promote the good. African Christians would interpret these means as gracious gifts of God and would pray for God's blessing upon its use. (p. 102)

Brand (2002:102-104) explains the working out of this principle: African Christians can utilise traditional African powers as the secondary means of their salvation. This is because God is concerned with all aspects of an African believer's life, and thus he provides traditional African powers as a means of promoting their spiritual security.

However, Brand and Wethmar's authorisation of African traditional powers seems to neglect the fundamental distinction between traditional African powers and Western medical specialists. This is because the traditional African view draws on a spiritual source for diagnosing and treating a variety of multifaceted problems, whilst the Western perspective is purely scientific and material, that is, not spiritually based. Perhaps, this is because Brand and Wethmar have ignored the impact of the Christian doctrine of creation in the West, which grounded the shift in Western culture from a belief in magic to the use of the scientific method upon which modern medical science is built (Torrance ${ }^{12}$ 1995: 47-48). One should acknowledge that Christ's redemption encompasses all aspects of life, including the dispelling of human beings' ignorance about God and his ways in the world, which extends to creation, and also to human perceptions about creation (Torrance 1996:203-204, 210).

Furthermore, Brand and Wethmar's understanding of the scope of Christ's person and saving work can be challenged, because their view depicts Christ as incapable of redeeming believers from their spiritual insecurity. If Christ's salvation is all-encompassing, spanning material and spiritual reality, then Christians' use of traditional African powers for their well-being is offensive to God, because it depends on other powers rather than God's power revealed through Christ. This implies that African Christians' use of traditional religious powers is an incorrect solution to the problem of spiritual insecurity. If this argument is warranted, any concurrence with Brand and Wethmar's position needs to be

12.Torrance (1995) argues that the long tradition of superstition in the Western world was liberated through 'its main missionary task in evangelising the world disseminating among the nations the saving knowledge of God, mediated through disseminating among the nations the saving knowledge of God, mediated through
Jesus Christ his Son, and providing the people of God throughout history with an articulate grasp of the substance of the faith' (p. 48) 
challenged, because it equates traditional African powers with Christ's power, on the basis that they both possess powers, which meet the needs of African Christians in different contexts and situations.

\section{A Biblical and pastoral evaluation of the African Christians' continual reliance in traditional African powers}

At this Christian interim period, African believers are not exempted from battling metaphysical forces. Ephesians 6:12 indicates that the battles of African believers (and all Christians) are not with flesh and blood, instead, they are against spiritual powers of darkness (cf. Adewuya 2012:251258 ). However, concerning the traditional African ancestors, this article establishes that the question is not whether the natural ancestors exist or not, instead, the question is whether the spirits of the deceased people are part of the spiritual powers which have a positive or negative influence on the lives of the living. In answering this question, Ecclesiastes 9:5-6 is clear that the spirits of deceased people have no part to play in anything that happens in this world.

In substantiating the above point, Igba (2013:121) recently undertook an exegetical study of Hebrews 12:1-2. His findings refuted some African theologians' usage of this passage as their basis for warranting African Christians' ongoing communication with their natural ancestors (cf. Nurnberger 2007:88). Even though we are only summarising Igba's interpretation, it is important to highlight that his explanation of the phrase 'the cloud of witness' in Hebrews 12:1 is worth quoting. Here, Igba (2013:121, cf. Nurnberger 2007:88) concludes that the cloud of witness in Hebrews 12:1 is not:

referring to departed ancestors that are involved in the life of the living, but as presentation of the ancestors as exemplars of faith; yet pointing the hearers to Jesus in 12:2 as the more excelling exemplar..$^{13}$

Furthermore, in the Old Testament, the neighbours of Israel that practiced the consultation of spiritual mediums, the offering of sacrifices to gods, divination and engagement in acts of witchcraft were condemned by God as evident in Deuteronomy 18:9-12. Here, it is important to note that Scripture is not acknowledging that human spirits exist as part of spiritual powers which exert influence on living

13.At this juncture, some African theologians like Kalengyo (2009:59) disagree with Igba's interpretation of Hebrews 12:1-2. In Kalengyo's (2009:59, cf. 60-66) reading, the cloud of witness in Hebrews 12:1 indicates the participation of the ancestors in the lives of the living people. However, Ellingworth (1993:639) and Jewet (1981:217) are in agreement with Igba's interpretation of Hebrews 12:1-2. In interpreting the cloud of witness of Hebrews 12:1, Ellingworth (1993:639) argues that in light of Hebrews 11, 'the author is moving to a powerful exhortation to his readers to hold fast to their faith of which Jesus is both the object and the supreme example'. The image of 'the cloud of witness' (in 12:1) and Jesus Christ (the author and perfecter of their faith) is aiming at 'enabling the pilgrims simply to drop the and perfecter of their faith) is aiming at 'enabling the pilgrims simply to drop the burden and go on, to shed one weight after another because the grace of Jesus Christ has made it superfluous' (Jewett 1981:217). Here, 'the permanent triumph of 'Christ' after his endurance of suffering at the cross has a huge significanc for believers (Ellingworth 1993:640-642). It gives Christians a 'Christocentric orientation" which assists them to conserve their faith as they associate themselves with their successful ultimate example, Jesus Christ (Jewett 1981:217, cf. Ellingworth 1993:640-642). people. Instead, these aforementioned evil acts are condemned by God because they are offensive to him (Dt 18:9-12, 14; 1 Sm 28:3, 9ff.; Ex 22:18) (cf. Turaki 1999:254). Therefore, Israel (as a covenantal and priestly nation of God) was commanded not to engage in these God-offending practices. That is, Israel was supposed to be a blameless nation before God. Any engagement in these evil acts incurred serious consequences. For example, these consequences are evidenced in 1 Chronicles 10:13-14, in which we encounter Saul's death as a result of consulting the spirit of Samuel through the mediation of a witch doctor.

Concerning the origin and nature of the spiritual powers which exert negative influence on African Christians, Kunhiyop (2012:55-59) gives a plausible outline of the similarities and the inconsistencies between the traditional African worldview and the biblical worldview in spiritual forces. He argues that the evil forces of African spirituality have real existence in Scripture; however the Bible classifies them as demons. These demons are fallen angels or spiritual beings, which were originally created as good yet capable of sin (Gn 1:9, 18, 21, 25 \& 31) (Kunhiyop 2012:55-59, cf. Ferdinando 1999:403). Some of these angels 'fell into sin and rebelled against God' (2 Pt 2:4; Jude 1ff.; Kunhiyop 2012:5559). Given this, many African theologians are of the opinion that the appearance of the ancestors in traditional African cultures is the various manifestations of Satan and his demons (Gehman 1989:139-142; Igba 2013:123; Nyirongo 1997:87). This implies that those who engage in such practices as the consultation of ancestral spirits are dabbling in the demonic. In saying this, we are not dismissing the traditional African beliefs in the negative influence of the spiritual powers in their lives as a myth of imagination, superstition, unscientific or irrational. That is, we are not following the route of some early Western missionaries who dismissed the existence of spiritual forces which have the power to exert negative influence in the lives of African people. Instead, at this critical point, we are arguing that the spiritual powers which impinge on physical reality exist as demons but not as human spirits who have influence over the living.

However, irrespective of what these spiritual powers are in Scripture or African thought, the salvation we have in Jesus Christ releases African believers from their fears and insecurities emanating from these spiritual forces. This is because Jesus Christ has disarmed the spiritual powers of darkness through his death and resurrection (Col 2:14). In other words, African believers are not to find their spiritual security from the placation of spiritual powers; rather, they are to be rooted and anchored in the knowledge that because of their eternal union and participation in Jesus Christ's redemptive person and work through faith, their security is in their salvation. Even though African Christians can feel physically, mentally and emotionally defeated in their battle against spiritual forces of darkness; in view of the effective nature and extent of Christ's salvation, this does not mean that they have lost the battle and need another means apart from Christ's salvation to secure them. We concur with Bediako (1994:111, cf. Letham 1993:152) that: 
The message is quite clear: the heart of the encounter of the good news with our context is our understanding of Jesus Christ, how our faith in Jesus Christ, crucified and risen, relates to our existence and destiny in the world. With such faith comes a firm conviction that in and through Christ, we have found and been found by, ultimate truth, which is utterly dependable for interpreting our human experience. We also are bound to discover that we are involved in a struggle to the death. It is not with flesh and blood, but with more subtle powers and intelligences who would hinder men and women from perceiving the nearness of Christ as one who has opened for us a new way, a living way, into the presence of God, through his own body and as one of us. (cf. Heb 10:20)

Nevertheless, as African Christians' continue to battle with the spiritual powers of darkness, they are to be reminded that they are foreigners or sojourners in this world (cf. Jn 17:16; 1 Pt 2:11; Phlp 3:20). They should live lives which do not conform to the sinful desires and patterns of this world corrupted through the first Adam ( $\operatorname{Rm} 5: 12,12: 2 ; 1 \mathrm{Pt} 2: 11 b)$. The perfect life which African Christians expect to have (at this overlapping age of Christianity) in Jesus Christ is not yet fully realised, because we are all waiting for his second coming to make everything new (Torrance 2009:256). Given this, we argue that at this Christian interim period, African Christians should be practically exhorted to be confident in their security in Jesus Christ irrespective of their multifaceted spiritual insecurities bound up with their existence in the first Adam. ${ }^{14}$ That is, as they struggle with their spiritual insecurity, African Christians are to stand firm by faith (Eph 6:16) in their accomplished salvation by Jesus Christ. This is none other than calling African Christians to develop a functional character of patience, hope and perseverance in the midst of their various spiritual insecurity challenges they face by placing their central focus on their now-but-not-yet fully realised victory in Jesus Christ. The truth is that African believers' slight momentary troubles are achieving for them an eternal glory that is far beyond comparison with their present situations (2 Cor 4:17).

\section{Conclusion}

There is a form of Christian syncretism operating in African Christians' use of traditional African powers (such as diviners) in addressing their spiritual insecurity challenges that arises from their former traditional African worldview of spiritual powers. This spiritual insecurity which still grips African Christians' arise from the spiritual powers such as the notions of a Supreme Being, lesser divinities, spirits and ancestors. There are three predominant views proposed by theological scholars as a response to the spiritual insecurity of African Christians. The first stance calls African Christians to discontinue with anything that is linked to traditional African spiritual worldview because Christianity entails a complete new ontological being. The second stance disapproves African Christians' reliance on traditional African powers and then proceeds to argue that Christian ministry should identify positives within the African

14. Here, we are merely acknowledging that we live in a world that still bears the
corruption that came through the first Adam. We are, however, new creations in corruption that came through the first Adam. We are, however, new creations in
Christ, our New Adam, even though we exist in such a world until Christ returns. spiritual world system and worldview that is useful and can be imported for use in contextualising the gospel. The third position advocates for Christians' continual reliance on traditional African spiritual powers in addressing their African contextual needs. Because these possible positions have their own strengths and weaknesses, we have revisited scripture in search of a more biblical-theological response to the spiritual insecurity of African Christians.

In using biblical passages from both the Old Testament (Dt 18:9-12, 14; $1 \mathrm{Sm}$ 28:3, 9ff.; Ex 22:18) and New Testament (Heb 12:1-2; Col 2:14), we underscored that African Christians should not continue to rely on traditional powers as a means of addressing their spiritual insecurity because it is offensive to God. From the New Testament perspective, irrespective of what these spiritual powers are in Scripture or African thought, the salvation we have in Jesus Christ releases African believers from their fears and insecurities emanating from these spiritual forces. This is because Jesus Christ has disarmed the spiritual powers of darkness through his death and resurrection ( $\mathrm{Col}$ 2:14). Thus, African believers are not to find their spiritual security from the placation of spiritual powers; rather, they are to be rooted and anchored in the knowledge that because their eternal union and participation in Jesus Christ's redemptive person and work through faith, their security is in their salvation.

\section{Acknowledgements Competing interests}

The authors declare that they have no financial or personal relationship(s) that may have inappropriately influenced them in writing this article.

\section{Authors' contributions}

Both authors were equally involved in conceptualising, researching, writing and editing the article for finalisation.

\section{References}

Adewuya, A.J., 2012, 'The spiritual powers of Ephesians 6:10-18 in the light of African Pentecostal spirituality', Bulletin for Biblical Research 22(2), 251-258.

Afeke, B. \& Verster, P., 2004, 'Christianisation of ancestor veneration within African traditional religion: An evaluation', In die Skriflig 38(1), 47-61. https://doi.org/ 10.4102/ids.v38i1.419

Agyarko, O.R., 2010, 'God of life: Rethinking the Akan Christian concept of God in the light of the ecological crisis', Ecumenical Review 65(1), 51-66. https://doi.org/ 10.1111/erev.12026

Aho Ekue, A.A., 2005, 'Troubled but not destroyed: The development of African theologies and the paradigm of theology of reconstruction', in K. Koschorke (ed.), African identities and world Christianity in the twentieth century, pp. 101-112, Harrassowitz, Wiesbaden.

Akins, C., 2000, 'Taboo', in S.A. Moreau (ed.), Evangelical dictionary of world missions, p. 928, Baker Books, Grand Rapids, MI.

Anderson, A., 2001, 'Stretching the definitions? Pneumatology and syncretism in African Pentecostalism', Journal of Pentecostal Theology 10(1), 98-111. https:// doi.org/10.1177/096673690101000106

Asamoah-Gyadu, K.J.A., 2009, 'Bediako, Kwame, 1945-2008: Bediako of Africa: A late 20th century outstanding theologian and a teacher', Mission Studies 26(1), 5-16. https://doi.org/10.1163/157338309X442335

Ashforth, A., 2001, 'On living in a world with witches: Every day epistemology and spiritual insecurity in a modern African city (Soweto)', in H.L. Moore \& T. Sanders (eds.), Magical interpretations, material realities: Modernity, witchcraft, and the occult in postcolonial Africa, pp. 206-225, Routledge, London.

Ashforth, A., 2005, Witchcraft, violence, and democracy in South Africa, University of Chicago Press, Chicago, IL. 
Banda, C., 2005, 'The sufficiency of Christ in Africa: A Christological challenge from African traditional religion', MA dissertation, Faculty of Theology, University of South Africa, Pretoria.

Bediako, K., 1992, Theology and identity: The impact of culture upon Christian thought in the second century and in modern Africa, Regnum Books, Oxford.

Bediako, K., 1995, Christianity in Africa: The renewal of a non-western religion Edinburgh University Press, Edinburgh

Bediako, K., 1999, 'Gospel and culture: Some insights for our time from the experience of the early church', Journal of African Christian Thought 2(2), 8-12.

Bediako, K., 2004, Jesus and the Gospel in Africa: History and experience, Orbis Book, New York.

Berinyuu, A.A., 1988, 'Transcultural approach to pastoral care of the sick in Ghana', Africa Theological Journal 16, 53-66.

Berinyuu, A.A. 2005, 'Pastoral Theology and Public Theology', in E. Graham \& A Rowlands (eds.), Pathways to the public square, pp. 147-156, Transaction Publishers, London.

Bowers, P., 2009, 'Christian intellectual responsibilities in modern Africa', Africa Journal of Evangelical Theology 28, 91-114.

Brand, G., 2002, Speaking of a fabulous ghost: In search of theological criteria, with special reference to the debate on salvation in African Christian theology, P. Lang, Frankfurt am Main.

Bujo, B., 1992, African theology in its social context, Orbis Books, Maryknoll, MO

Buthelezi, J.S., 2011, 'A critical analysis of the doctrine of salvation in Free Evangelical Assemblies in Swaziland: A contextualized theology', MA Dissertation, Faculty of Theology, South African Theological Seminary, Johannesburg.

Chitando, E., 2005, 'Missionary attitudes towards African Traditional Religions and Hinduism: A comparative survey', in K. Koschorke (ed.), African identities and world Christianity in the twentieth century, pp. 181-197, Harrassowitz, Wiesbaden.

Dyrness, W.A., 1990, Learning about theology from the third world, Zondervan, Grand Rapids, MI.

Ejenobo, D.T., 2009, 'The mystical element in Paul's theology of the Holy Spirit: An African interpretation', Asia Journal of Theology 23(1), 69-81.

Ellingworth, P., 1993, The epistle to the Hebrews: A commentary on the Greek Text, William B. Eerdmans, Grand Rapids, MI.

Ferdinando, K., 1999, The Triumph of Christ in African perspective: A study of Demonology and Redemption in the African context, Paternoster, Carlisle.

Gathogo, J., 2007, 'African theology of reconstruction as a practical theology for all', Practical Theology in South Africa 24(2), 99-121.

Gehman, R.J., 1989, African traditional religion in biblical perspective, East African Educational Publishers, Nairobi.

Haar, G.T., 2007, 'Introduction: The evil called witchcraft', in G. Haar (ed.), Imagining evil: Witchcraft beliefs and accusations in contemporary Africa, pp. 1-30, Africa World Press, Trenton NJ.

Hastings, A., 1976, African Christianity, Seabury Press, New York.

Hesselgrave, D.J., 1991, Communicating Christ cross culturally: An introduction to missionary communication, Zondervan, Grand Rapids, MI.

Hiebert, P.G., 2008, Transforming worldviews: An anthropological understanding of how people change, Baker Academic, Grand Rapids, MI.

Hood, R.E., 1990, Must God remain Greek? Afro cultures and God-talk, Fortress, Minneapolis, MN.

Idowu, E.B., 1973, African traditional religion: A definition, Orbis Books, Maryknoll, NY.

Igba, J., 2013, 'Ancestor Christology and Jesus' identity: A study based in the epistle to the Hebrews', MA dissertation, Faculty of Theology, North West University, North West.

Imasogie, O., 1983, Guidelines for Christian theology in Africa, Africa Christian Press, Achimota.

Ishola, A.S., 2002, 'Christianity vis-à-vis Traditional Religions', Southwestern Journal of Theology 44(2), 44-60.

Jewett, R., 1981, Letter to Pilgrims: A commentary on the epistle to the Hebrews, The Pilgrim Press, New York.

Kabasele, F., 1991, 'Christ as ancestor and elder brother', in R. Schreiter (ed.), Faces of Jesus in Africa, pp. 123-124, Orbis Books, Maryknoll, MO

Kalengyo, E.M., 2009, 'Cloud of witness in Hebrews 12:1 and Ganda ancestors: An incarnational reflection', Neotestamentica 43, 49-68.

Kalu, O.U., 2007, African Christianity: An African story, Africa World Press, Trenton, NJ.

Kato, B.H., 1975, Theological pitfalls in Africa, Evangel Publishing House, Kisumu.

Kok, D.B., 2005, Christianity and African Traditional Religion: Two realities of a different kind, Kachere Series, Zomba.

Kraft, C.H., 1999, 'Culture, world-view and contextualisation', in R.D. Winter \& S.C. Hawthorne (eds.), Perspectives on the world Christian Movement, 3rd edn., pp. 384-391, William Carey Library, Pasadena, CA.

Kunhiyop, S.W., 2012, African Christian theology, Zondervan, Grand Rapids, MI.

Kwesi, D., 1984, Theology in Africa, Orbis Books, Maryknoll, MO.

Letham, R., 1993, The work of Christ: Contours of Christian theology, InterVarsity Press, Downers Grove, IL.

Light, V.E., 2010, The evangelical church in Africa: Towards a model for Christian discipleship, South African Theological Seminary, Johannesburg.
Louw, D., 2008, Cura vitae: Illness and the healing of life in pastoral care and counselling, Lux Verbi, Cape Town.

Louw, D.J., 2002, 'A practical theological ecclesiological of relocalisation and globalisation from below: Towards a viable African Renaissance', Journal of Theology for Southern Africa 112, 69-87.

Lugira, A.M., 2009, World Religions: African traditional religion, 3rd edn., Chelsea House Publishers, New York.

Magezi, V., 2006, 'Community and the role of pastoral care to the ill in Africa', Die Skriflig 40(3), 1-17. https://doi.org/10.4102/ids.v40i3.356

Magezi, V., 2007, 'Pastoral counseling: Towards a diagnostic and interpretational approach in Africa', Die Skriflig 41(4), 655-672. https://doi.org/10.4102/ids. v41i4.325

Magezi, V., 2010, Pastoral care in tension between tradition and modernity: Pastoral ministry and biblical response to challenges of fear of death, fear of spirits and hospitality in Africa, Lambert Academic Publishing, Saarbrücken, Germany.

Magezi, V., 2016, 'Reflection on pastoral care in Africa: Towards discerning emerging pragmatic pastoral ministerial responses', In die Skriflig 50(1), a2130. https://doi. org/10.4102/ids.v50i1.2130

Maimela, S.S., 1991, 'Traditional African anthropology and Christian Theology', Journal of Theology for South Africa 76, 4-14.

Masamba ma Mpolo, 2013, 'Spirituality and counselling for liberation: The context and praxis of African pastoral activities and psychology', in K. Federschmidt, K. Temme \& H. Weiss (eds.), Voices from Africa on pastoral care: Contributions in international seminars 1988-2008, pp. 7-18, Magazine of the Society for Intercultural Pastoral Care and Counselling (SIPCC), viewed 10 March 2016, from http://www1.ekir.de/sipcc/downloads/IPCC-020-txt.pdf

Mashau, D.T., 2009, 'A reformed missional perspective on secularism and pluralism in Africa: Their impact on African Christianity and the revival of Traditional Religion', Calvin Theological Journal 44(1), 108-126.

Mbiti, J., 1970, Concepts of God in Africa, SPCK, London.

Mbiti, J., 1989, African religions and philosophy, Heinemann, London.

Michael, M., 2013, Christian theology and African traditions, Lutterworth Press, Cambridge.

Milingo, E., 1984, The world in between: Christian healing and the struggle for spiritual survival, Orbis Books, Maryknoll, MO

Mwaura, P.N., 1994, 'Healing as a pastoral concern', in D.W. Waruta \& H.W. Kinot (eds.), Pastoral care in African Christianity, pp. 62-102, Acton Publishers, Nairobi.

Mwaura, P.N., 2006, 'The anthropological dimension of a patient's treatment: $A$ response to Prof. Bernard Ugeux', International Review of Mission 95(376/377) 136-142. https://doi.org/10.1111/j.1758-6631.2006.tb00548.x

Nakah, V., 2006, 'Evangelical Christianity and African culture', PhD thesis, University of Stellenbosch, Cape Town.

Naugle, D.K., 2002, Worldview: The history of a concept, W.B. Eerdmans, Grand Rapids, Ml.

Nurnberger, K., 2007, The living dead and the living God: Christ and the ancestors in changing Africa, CB Powell Bible Centre, Pretoria.

Nyamiti, C., 2006, Studies in African Christian theology, vol. 2: Jesus Christ, the ancestor of humankind: An essay on African Christianity, CUEA Publications, Nairobi.

Nyirongo, L., 1997, The Gods of Africa or the God of the Bible? The snares of African traditional religion in Biblical perspective, Potchefstroom Universiteit, Vir Christelike Hoer Onderwys.

Oladosu, O.A., 2012, 'Ancestral veneration in the religious expression of the indigenous Aladura Churches', Ogbomoso Journal of Theology 17(2), 159-171.

Olsen, J.H., 1997, 'Contextualised Christology in tropical Africa', Svensk Missionstidskrift 85(3-4), 247-267.

Oxford advanced learner's dictionary of International student's Edition, New 8th edn. 2010, Oxford University Press, Oxford.

Palmer, T., 2008, 'Jesus Christ: Our ancestor?', Africa Journal of Evangelical Theology 27(1), 65-76.

Pobee, J., 1979, Towards an African theology, Abingdon, Nashville, TN.

Potgieter, R. \& Magezi, C., 2016, 'A critical assessment of Bediako's incarnational Christological model as a response to the foreignness of Christ in African Christianity', In die Skriflig 50(1), a2136. https://doi.org/10.4102/ids.v50i1.2136

Reed, R. \& Mtukwa, G., 2010, 'Christ our ancestor: African Christology and the danger of contextualization', Wesleyan Theological Journal 45(1), 144-163.

Salala, C., 1998, 'The world of the spirits: Basukuma Traditional Religion and biblical Christianity', in S. Ngewa, M. Shaw \& T. Tienou (eds.), Issues in African theology, pp. 133-138, East African Education Publishers, Nairobi.

Sogolo, G.S., 1991, 'The concept of cause in African thought', in P.H. Cotzee \& A.P.J. Roux (eds.), Philosophy from Africa: A text with readings, pp. 177-185, Oxford Roux (eds.), Philosophy fror
University Press, Oxford.

Stinton, D.B., 2004, Jesus of Africa: Voices of contemporary African Theology, Orbis Books, Maryknoll, NY.

Taylor, J.V., 1963, The primal vision: Christian presence amid African religion, SCM, London.

Torrance, T.F., 1996, The Christian doctrine of God: One being three persons, T \& T Clark, Edinburgh.

Torrance, T.F., 2009, Atonement: The person and work of Christ, IVP Academic, Downers Grove, IL. 
Triebel, J., 2002, 'Living together with the ancestors: Ancestor veneration in Africa as a challenge for missiology', Missiology: An International Review 30(2), 187-197.

Turaki, Y., 1999, Christianity and the African Gods. A method in theology, Potchefstroom University, Potchefstroom.

Turaki, Y., 2006, Foundations of African traditional religion and world-view, Word Alive Publishers, Nairobi.

Wagenaar, H., 1999, 'Theology, identity and the pre-Christian past: A critical analysis of Dr. Bediako's theology from a Frisian perspective', International Review of Mission 88(351), 364-380. https://doi.org/10.1111/j.1758-6631.1999.tb00165.x
Westerlund, D., 2006, African indigenous religions and disease causation from spiritual beings to living humans, Brill, Leiden.

Westerlund, D., 2011, 'Spiritual beings as agents of illness', in J.K. Olupona (ed.), African spirituality: Forms, meanings and expressions, pp. 119-147, The Crossroad Publishing, New York.

Wethmar, C., 2006, 'Conceptualization of evil in African Christian theology', Acta Theological Journal 1, 249-257.

Wijsen, F., 2000, 'Popular Christianity in East Africa: Inculturation and syncretism', Exchange 29(1), 37-60. https://doi.org/10.1163/157254300X00049 